\title{
Problematyka wyznaczania i aktualizacji obszarów rozliczeniowych ciepła spalania oraz obszarów nawaniania z wykorzystaniem urządzeń do zdalnego pomiaru parametrów jakościowych
}

\begin{abstract}
W artykule zostały przedstawione zagadnienia i propozycje rozwiązań związane z wyznaczaniem i aktualizacją obszarów rozliczeniowych ciepła spalania (ORCS) oraz sposób wykorzystania automatycznych analizatorów do pomiaru stężenia THT w gazie ziemnym na podstawie wieloletnich doświadczeń w Polskiej Spółce Gazownictwa.

Słowa kluczowe: ORCS, ciepło spalania, obszar nawaniania, strefa nawaniania, analizator THT.

\section{The issue of determining and updating Area Clearing Heat of Combustion and areas odoration using modern remote measurement of quality parameters}

The article presents the issues and proposals of solutions, for designating and updating the Area Clearing Heat of Combustion, and proposals for the use of automatic analyzers, to measure the concentration of THT in natural gas based on many years of experience, in the Polish Gas Company.
\end{abstract}

Key words: ORCS, heat of combustion, area odoration, odoration zone, analyzer THT.

\section{Wstęp}

Na podstawie rozporządzenia Ministra Gospodarki z dnia 28 czerwca 2013 roku w sprawie szczegółowych zasad kształtowania i kalkulacji taryf oraz rozliczeń w obrocie paliwami gazowymi [2] Polska od 1 sierpnia 2014 roku dołączyła do grona państw europejskich, które w rozliczeniach stosują jednostki energii. Taki sposób rozliczeń ma ułatwić dokonywanie transakcji międzynarodowych, porównywanie opłat i tym samym zapewnić przejrzystość rozliczeń uczestników rynku - powstaje jednak pytanie, czy także odbiorców końcowych. W obecnej sytuacji przedsiębiorstwa energetyczne zajmujące się transportem paliwa gazowego nie są w stanie, ze względów technicznych i ekonomicznych, zapewnić rozliczeń $w$ jednostkach energii na podstawie indywidualnych wskazań urządzeń pomiarowych. $Z$ tego względu należy stosować pewne założenia i uśrednienia, zgodne z rozporządzeniem [2], które niestety powodują rozbieżności w rozli- czeniach oraz wątpliwości odbiorców końcowych. Kluczowe jest prawidłowe dobranie punktów pomiaru parametrów jakościowych i właściwy nadzór nad prawidłowością wskazań urządzeń realizujących te pomiary, które obecnie nie są objęte żadnymi regulacjami wyższego rzędu. Analogiczna problematyka dotyczy kolejnego parametru jakościowego, jakim jest poziom nawonienia gazu ziemnego. Gaz ziemny powinien być nawoniony przez przedsiębiorstwo energetyczne zajmujące się dystrybucją paliwa gazowego w sieciach dystrybucyjnych o ciśnieniu roboczym nie wyższym niż 0,5 MPa do zapachu wyraźnie wyczuwalnego przy określonym stężeniu gazu w powietrzu. Zapisy rozporządzenia Ministra Gospodarki z dnia 2 lipca 2010 roku w sprawie szczegółowych warunków funkcjonowania systemu gazowego [3] wymuszają weryfikację tego parametru z częstotliwością raz na dwa tygodnie, nie precyzując zasad i sposobu 
wykonywania pomiarów dla poszczególnych obszarów, których PSG wyznaczyło obecnie ponad 1200 . W celu realizacji postanowień wspomnianych regulacji $[2,3]$, zapewnienia prawidłowości rozliczeń oraz bezpieczeństwa dostaw paliwa gazowego PSG jako operator podjęła działania optymalizujące, omówione w dalszej części artykułu.

\section{Przedstawienie stanu obecnego ORCS}

Na początku zacznijmy od zdefiniowania, co to jest ORCS - to obszar systemu dystrybucyjnego wydzielony w taki sposób, aby wyznaczona średnia ważona wartość ciepła spalania na tym obszarze nie różniła się więcej niż o $\pm 3 \%$ od wartości ciepła spalania określonej w którymkolwiek punkcie tego obszaru. W większości przypadków najmniejszym wyznaczanym ORCS przez PSG jest strefa dystrybucyjna, jako obszar systemu dystrybucyjnego połączony hydraulicznie i zasilany z określonego punktu lub punktów wejścia. W przypadku gdy do strefy dystrybucyjnej z jednego lub kilku punktów wejścia dostarczane jest paliwo gazowe o cieple spalania znacznie odbiegającym od pozostałych punktów, uniemożliwiając spełnienie w strefie dystrybucyjnej kryterium określonego do utworzenia ORCS, należy dokonywać podziału strefy dystrybucyjnej. W wyniku między innymi tych uwarunkowań obecnie w PSG są wydzielone 224 takie obszary, dla których należy wyznaczać i publikować ciepło spalania dla każdego miesiąca najpóźniej 3. dnia następnego miesiąca do godziny 11:00. Szczegółowy wykaz liczby ORCS zamieszczono w tablicy 1.

Tablica 1. Wykaz ORCS w PSG

\begin{tabular}{|l|c|}
\hline \multicolumn{1}{|c|}{ Oddział } & Liczba ORCS \\
\hline Gdańsk & 10 \\
\hline Poznań & 26 \\
\hline Tarnów & 123 \\
\hline Warszawa & 7 \\
\hline Wrocław & 12 \\
\hline Zabrze Lącznie & $\mathbf{2 2 4}$ \\
\hline \multicolumn{2}{|r|}{} \\
\hline
\end{tabular}

Podstawowym czynnikiem, który wpływa na tak dużą liczbę ORCS, jest zmienność w czasie kierunków zasilania poszczególnych obszarów, co mogłoby się wiązać z niedotrzymaniem warunku $\pm 3 \%$ w odniesieniu do wartości ciepła spalania, o którym mowa powyżej. Chcąc zapewnić spełnienie powyższego warunku w każdym punkcie wyznaczonego obszaru, dzielony jest on na mniejsze, w których warunek jest spełniony nawet $\mathrm{w}$ przypadku wystąpienia sporadycznej (występującej $1 \div 2$ razy w roku) sytuacji związanej ze zmianą kierunków zasilania. Kolejnymi czynnikami wpływającymi na liczebność ORCS jest duża liczba punktów wejścia do systemu dystrybucyjnego będących źródłami (w tym kopalnie i LNG) oraz różne rodzaje transportowanego gazu, dla których ze względu na zmienność składu gazu wyznaczane są odrębne ORCS. W celu zobrazowania zagadnienia tablica 2 przedstawia liczbę punktów wejścia będących źródłami dla systemu dystrybucyjnego PSG.

Tablica 2. Liczba punktów wejścia będących źródłami

\begin{tabular}{|l|c|}
\hline \multicolumn{1}{|c|}{ Rodzaj źródła } & Liczba źródeł \\
\hline Kopalnia & 46 \\
\hline LNG & 7 \\
\hline Mieszalnie gazu & 3 \\
\hline
\end{tabular}

Siecią dystrybucyjną PSG transportowane są gazy E, Lw, Ls, LNG oraz do 15 maja 2015 roku również gazy propan-butan-powietrze i propan-butan rozprężony, które zostały obecnie zastąpione gazem LNG, wymagającym wyznaczenia odrębnego ORCS dla każdego obszaru.

\section{Wyznaczanie i aktualizacja ORCS}

Dotychczasowe uwarunkowania formalne oraz zaszłości historyczne w poszczególnych oddziałach PSG spowodowały, że występuje zróżnicowane podejście do wyznaczania ORCS. Część oddziałów wybrała kierunek bardzo zachowawczy i wyznaczyła maksymalną liczbę ORCS, która uwzględnia wszystkie sytuacje mogące zaistnieć na sieci, nawet jeżeli prawdopodobieństwo ich wystąpienia jest minimalne. Natomiast są też oddziały, które zdecydowały się na odmienne rozwiązanie i wyznaczyły tylko niezbędną liczbę ORCS, wystarczającą w bieżących warunkach funk- cjonowania systemu. Nie ma jednoznacznej odpowiedzi na pytanie, jakie rozwiązanie jest korzystniejsze, gdyż z jednej strony zostały zabezpieczone wszystkie mogące wystąpić sytuacje na sieci i nie trzeba wyznaczać w pośpiechu nowego ORCS, a z drugiej strony duża liczba ORCS publikowana na stronie internetowej PSG może być różnie interpretowana przez naszych odbiorców. Część z nich tak dużą liczbę ORCS odbierze jako staranność PSG w zakresie dokładnego określenia ciepła spalania na poszczególnych obszarach, natomiast druga grupa może to postrzegać jako sygnał bardzo 
dużego stopnia zróżnicowania kaloryczności dystrybuowanego gazu w sieci i może mieć wątpliwości co do określonego ciepła spalania. Ważne jest wypracowanie wspólnych zasad wyznaczania ORCS, które zapewnią ich optymalną liczbę i dokonanie aktualizacji stanu obecnego tak, aby odbiorca posiadający punkty poboru gazu w dwóch różnych oddziałach miał w analogiczny sposób wyznaczony ORCS i tym samym ciepło spalania. Niezbędne do realizacji powyższego jest stworzenie systemu, w którym w sposób dynamiczny mogłoby się odbywać wyznaczanie ORCS i publikacja ciepła spalania, z możliwością wyszukiwania po wprowadzeniu danych punktu poboru i okresu. Obecnie w PSG trwają prace nad uruchomieniem takiego systemu, powiązanego z mapą systemu dystrybucyjnego, na bazie dotychczas funkcjonujących rozwiązań w niektórych oddziałach. Do podstawowych funkcjonalności, jakimi miałby się charakteryzować ten system, należy zaliczyć:

- wizualizację zasięgu ORCS z dokładnością do pojedynczej gminy/miejscowości,

- aktualizację zasięgu ORCS i wartości ciepła spalania,

- możliwość wskazywania na mapie lub wyszukiwania miejscowości i otrzymania dla niej przynależności do ORCS i obowiązującego ciepła spalania w danym okresie,
- $\quad$ archiwizację danych o ORCS i cieple spalania przez okres minimalny 5 lat,

- aktualizację miejscowości na podstawie danych bazy TERYT, z zachowaniem już wprowadzonych danych,

- narzędzie do weryfikacji spełnienia warunku $\pm 3 \%$ w odniesieniu do wartości ciepła spalania dla wszystkich istniejących ORCS na bazie danych z pomiarów wewnętrznych oraz chromatografów zainstalowanych na sieci PSG i operatorów systemów współpracujących (OSW),

- publikowanie wartości ciepła spalania włącznie z informacjami dotyczącymi numeru ORCS, wartości ciepła spalania w jednostkach $\left[\mathrm{MJ} / \mathrm{m}^{3}\right]$, współczynnika konwersji $\left[\mathrm{kWh} / \mathrm{m}^{3}\right]$ oraz daty publikacji za dany miesiąc rozliczeniowy.

Najistotniejszym elementem z powyżej wymienionych funkcjonalności będzie narzędzie do weryfikacji spełnienia warunku $\pm 3 \%$ na podstawie wykonywanych pomiarów wewnętrznych (chromatografy procesowe, pomiary laboratoryjne), danych z chromatografów odbiorców oraz OSW, w tym kopalń i innych źródeł. Kluczowe w realizacji tego elementu jest wyznaczenie punktów do weryfikacji i nawiązanie współpracy w zakresie wymiany danych o wartości ciepła spalania $\mathrm{z}$ innymi podmiotami na rynku gazu w Polsce.

\section{Określanie ciepła spalania}

Wyznaczanie ciepła spalania, na podstawie którego rozliczani są odbiorcy końcowi, w większości przypadków odbywa się na bazie danych pozyskiwanych od operatora gazociągów przesyłowych (OGP). Wartość ciepła spalania dla poszczególnych ORCS jest wyznaczana jako średnioważona ze wszystkich punktów wejścia na danym ORCS. Niezbędne dane do określenia średnioważonego ciepła spalania w poszczególnych ORCS to oprócz kaloryczności także ilość wprowadzonego gazu do sieci PSG w każdym punkcie wejścia. Mając takie uzgodnione dane, można przystąpić do obliczeń, które należy wykonać z należytą starannością oraz zaokrąglić wynik, a tutaj pojawiają się nieznaczne różnice na trzecim lub czwartym miejscu po przecinku. Takie różnice nie mają większego znaczenia w rozliczeniach z odbiorcami indywidualnymi, natomiast są istotne w przypadku odbiorców przemysłowych, pobierających setki tysięcy $\mathrm{m}^{3}$ gazu. Między innymi z tych względów niektórzy z odbiorców przemysłowych wystąpili już o możliwość rozliczania ich na podstawie indywidualnego ciepła spalania określonego na podstawie zainstalowanego w punkcie odbioru chromatografu, stanowiącego własność odbiorcy. Istotnym czynnikiem mającym wpływ na jakość danych do określenia średnioważonego ciepła spalania jest wymóg wynikający z rozporządzenia [2] dotyczący terminu publikacji danych przez operatorów. Bardzo często zdarza się taki układ kalendarza, który uniemożliwia wykonanie tych czynności w dni robocze, i muszą być one realizowane w dni świąteczne i wolne od pracy dla służb zajmujących się tym zagadnieniem. Należałoby podjąć działania legislacyjne zmieniające termin publikacji tych danych na 3. dzień roboczy. Taka zmiana nie będzie miała wpływu na rozliczenie odbiorców końcowych, a wręcz przyczyni się do uzyskania danych o wyższej jakości. Oczywiście na jakość danych wpływ mają przede wszystkim informacje pozyskiwane $\mathrm{z}$ chromatografów, które obecnie są w większości nadzorowane według Standardu Technicznego ST-IGG-0205:2015 Ocena jakości gazów ziemnych. Część 1: Chromatografy gazowe procesowe do analizy składu gazu ziemnego, ale nie znajdują te wymagania odzwierciedlenia w regulacjach państwowych. Usankcjonowanie tych urządzeń przepisami prawa pozwoliłoby na objęcie całego toru pomiarowego niezbędnego do określenia energii prawną kontrolą metrologiczną, ale zagadnienie to wykracza poza ramy niniejszego artykułu. 


\section{Wyznaczanie stref i obszarów nawaniania}

Zdobyta wiedza i doświadczenia znalazły swoje odzwierciedlenie $\mathrm{w}$ instrukcji prowadzenia nadzoru nad nawonieniem gazu ziemnego w PSG. Na jej podstawie stworzono pojęcia strefa i obszar nawaniania, które ułatwiają prowadzenie monitoringu tego procesu przy zachowaniu bezpieczeństwa dostaw. Poniżej przedstawiono definicje wymienionych pojęć zgodne z instrukcją [1]:

Strefa nawaniania - umownie wydzielony fragment systemu dystrybucyjnego, obejmujący gazociągi niskiego, średniego - a w uzasadnionych przypadkach - średniego podwyższonego i wysokiego ciśnienia, połączony hydraulicznie i zasilany z jednej lub wielu nawanialni.

Obszar nawaniania - umownie wydzielony fragment strefy nawaniania, na którym przyjmuje się homogeniczność stężenia THT, przy uwzględnieniu podziału na sieć średniego i niskiego ciśnienia. Na obszarze tym gaz ziemny nawaniany jest $\mathrm{z}$ jednej nawanialni.

Strefy nawaniania określane są na podstawie uwarunkowań technicznych, takich jak topologia sieci czy kierunki zasilania połączonych ze sobą hydraulicznie sieci gazowych. Obszar nawaniania, w ramach wyznaczonej strefy nawaniania, można wyznaczyć w specjalnym programie do symulacji sieci gazowych. Na etapie przygotowania danych należy określić parametry, na przykład wartość ciepła spalania, odrębnie dla każdej ze stacji gazowych zasilających daną strefę nawaniania. Określenie obszaru nawaniania polega na wyodrębnieniu z wyników symulacji obszaru, na którym analizowany parametr ma stałą wartość i zgodną z wartością w źródle. Obszary, na których badany parametr jest wypadkową parametrów ze źródeł, stanowią obszar mieszania, w którym nie należy planować montażu analizatorów.

Wszystkie obszary nawaniania powinny posiadać punkty nadzoru, z których wyniki wykonanych analiz stężenia THT w gazie ziemnym służą do określenia prawidłowości przebiegu procesu nawaniania. Ze względu na bardzo dużą liczbę punktów do nadzorowania tego procesu - wprowadzono możliwość zastąpienia pomiarów ze wszystkich wyznaczonych punktów pomiarami z automatycznego analizatora THT, na zasadach opisanych w dalszej części artykułu. W przypadku gdy strefa nawaniania jest zasilana gazem nawanianym z jednej nawanialni, obszar nawaniania jest tożsamy, a wyniki symulacji służą do określenia przepływów w celu wyznaczenia tych punktów nadzoru, które mają być przeznaczone do montażu analizatora. Obszary nawaniania wyznacza się

Przykładowy obszar / strefa nawaniania

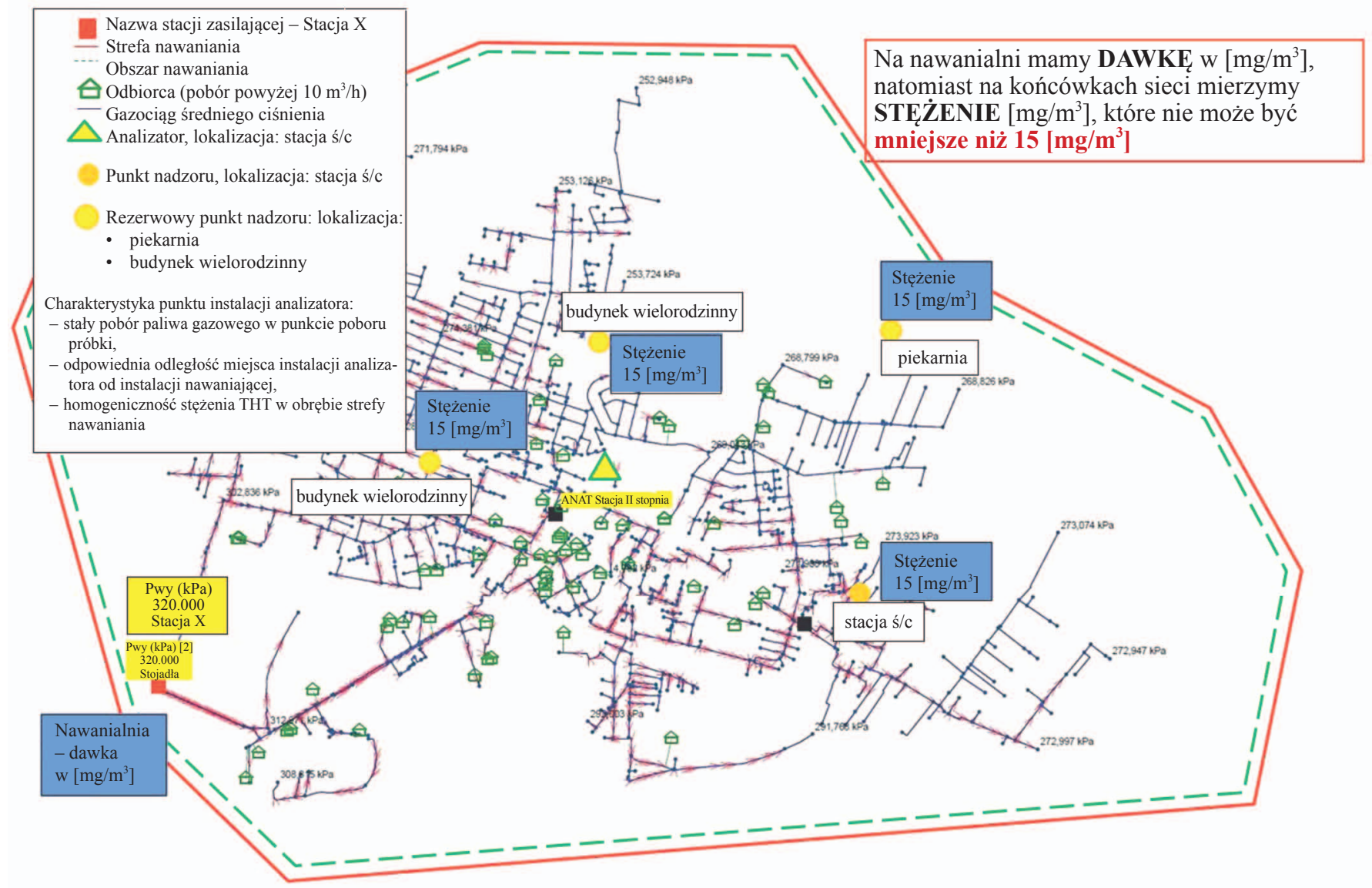


poprzez wydzielenie terenu homogenicznego pod względem stężenia THT w strefach nawaniania, w których może być, jest lub będzie zainstalowany analizator. Możliwe jest ustanowienie kilku obszarów nawaniania w obrębie danej strefy nawaniania. Obszar nawaniania wyznacza się w przypadku zamontowania lub możliwości zamontowania w tym obszarze analizatora, który zapewni nadzór nad zachowaniem wymaganego stężenia THT zgodnie z instrukcją [1]. Określenie obszaru nawaniania w przypadku strefy nawaniania, na terenie której gaz ziemny jest nawaniany z kilku instalacji nawaniających, powinno być wykonane na podstawie wyników symulacji sieci gazowej dla okresów największego i najmniejszego poboru gazu ziemnego. Przykładowy obszar nawaniania przedstawiono na rysunku 1 .

Wyniki symulacji, o której mowa powyżej, winny być zaprezentowane w postaci graficznej (mapy) z zaznaczony- mi zasięgami oddziaływania poszczególnych nawanialni, naniesionymi punktami nadzoru oraz miejscami, w których może być, jest lub będzie zainstalowany analizator. Ze względu na zmienność parametrów pracy sieci niezbędna jest weryfikacja wyznaczonych obszarów nawaniania, która może nastąpić na drodze doświadczalnej na podstawie pomiarów stężenia THT w gazie ziemnym, np. w czasie przewonienia gazu ziemnego, wykonanego nierównocześnie na poszczególnych nawanialniach zasilających dany obszar nawaniania. W PSG na bazie doświadczeń zostało przyjęte, że weryfikacja wyznaczonych obszarów nawaniania musi być przeprowadzona nie rzadziej niż raz na trzy lata, chyba że w wyniku procesu inwestycyjnego lub z innych względów zmieni się układ zasilania $\mathrm{w}$ danej strefie dystrybucyjnej - w takim przypadku należy niezwłocznie ponownie określić obszary nawaniania i dokonać ich weryfikacji.

\section{Monitorowanie poziomu THT za pomocą analizatorów}

Polska Spółka Gazownictwa Sp. z o.o. na podstawie rozporządzenia [3] została zobligowana do zapewnienia odpowiednich standardów jakościowych obsługi odbiorców, a co się z tym wiąże - do dostarczania gazu ziemnego, który musi posiadać odpowiedni poziom nawonienia. Weryfikacja skuteczności procesu nawonienia musi być dokonywana systematycznie nie rzadziej niż raz na dwa tygodnie, co przy wspomnianej wcześniej liczbie obszarów nawaniania, na których występuje od 3 do 8 punktów nadzoru, powoduje duże trudności. Na podstawie obowiązujących regulacji wewnętrznych w PSG oraz zbieranych od 2005 roku doświadczeń została stwierdzona zasadność stosowania automatycznych analizatorów do pomiaru stężenia THT w gazie ziemnym. Montaż tych urządzeń w strefach dystrybucyjnych powoduje ograniczenie wyjazdów służb eksploatacyjnych do punktów nadzoru dla danego obszaru nawaniania, poprawia bezpieczeństwo dostaw dzięki bieżącemu monitoringowi poziomu nawonienia, a tym samym pozwala zrealizować zapisy powyższego rozporządzenia. Przez niespełna 10 lat w obecnych oddziałach PSG w różnym tempie rozwijało się wykorzystanie tego typu urządzeń, dlatego też została przygotowana koncepcja ogólnopolska. Zgodnie z nią należy dążyć do instalowania powyższych urządzeń we wszystkich strefach nawaniania, gdzie jest to uzasadnione ekonomicznie lub wynika z innych uwarunkowań technicznych. Model docelowy zakłada instalację analizatorów w jak największej liczbie stref nawaniania w celu poprawy bezpieczeństwa, optymalizacji procesu kontroli nawonienia oraz poprawy samego procesu nawonienia (zadawania dawki). W przypadku instalacji nowych nawanialni lub modernizacji istniejących należy też dążyć, aby umożliwiały one zdalne zmiany dawki na podstawie wskazań analizatorów. Takie podejście pozwoli zautomatyzować cały proces nawaniania. W tablicy 3 przedstawiono stan obecny wyposażenia PSG w analizatory oraz plan ich montażu w IV kwartale 2016 roku.

Tablica 3. Liczba analizatorów w PSG

\begin{tabular}{|l|c|c|}
\hline Oddział & $\begin{array}{c}\text { Obecna liczba } \\
\text { analizatorów } \\
\text { [szt.] }\end{array}$ & $\begin{array}{c}\text { Montaż analizatorów } \\
\text { w IV kw. 2016 roku } \\
\text { [szt.] }\end{array}$ \\
\hline Gdańsk & 17 & 2 \\
\hline Poznań & 0 & 0 \\
\hline Tarnów & 48 & 5 \\
\hline Warszawa & 165 & 4 \\
\hline Wrocław & 2 & 6 \\
\hline Zabrze & 0 & 3 \\
\hline Lącznie & $\mathbf{2 3 2}$ & $\mathbf{2 0}$ \\
\hline
\end{tabular}

Monitorowanie stężenia THT w sieci wykonywane jest obecnie za pomocą:

- analizatorów przesyłających wyniki drogą telemetryczną, - urządzeń przenośnych,

- chromatografów stacjonarnych - na podstawie dostarczonych próbek gazu.

W niniejszym artykule skupiono się na wykorzystaniu do pomiarów stężenia THT analizatorów, które są nadzorowane przez 24 godziny na dobę, a w przypadku wystąpienia nieprawidłowości niezwłocznie podejmuje się działania zaradcze. Pomiary w tych urządzeniach są wykonywane według ustalonego harmonogramu. Z doświadczeń wynika, że optymalny odstęp między pomiarami to 4 godziny, przy czym 
zawsze można go zmienić lub wymusić zdalnie pomiar w danej chwili. W celu upewnienia się, że pomiary wykonywane przez analizator są właściwe i reprezentatywne, konieczna jest - oprócz właściwego dbania o stan urządzenia - właściwa lokalizacja i wyznaczenie odpowiedniej korelacji pomiarów na danej sieci. W związku z powyższym wypracowano w PSG metodologię wyznaczania korelacji, która gwarantuje zapewnienie minimalnego poziomu THT w całej sieci w rozpatrywanej strefie/obszarze nawaniania i wyczuwalność zapachu zgodną z rozporządzeniem [3]. Poniżej przedstawiono kilka kluczowych zasad oraz szczegółową metodologię określania minimalnego stężenia THT, jakie musi być stwierdzone przez analizator, aby zapewnić bezpieczeństwo. Po instalacji nowego analizatora należy niezwłocznie wykonać sprawdzenie korelacji jego wskazań z wynikami pomiarów w poszczególnych punktach nadzoru. Weryfikację taką należy również przeprowadzić miesiąc po wyznaczeniu stopnia tłumienia stężenia THT. Dla każdego zainstalowanego analizatora powinna być sprawdzona korelacja pomiędzy wynikami pomiaru analizatora a pomiarami fizycznie wykonywanymi w poszczególnych punktach nadzoru poziomu nawonienia. Sprawdzenie powinno być przeprowadzone dla nastaw nawanialni w okresie letnim i zimowym. Okres letni i zimowy nastaw nawanialni i minimalnego stężenia THT w miejscu montażu analizatora obowiązuje zgodnie $\mathrm{z}$ instrukcją [1]:

- od 1 kwietnia do 31 października - okres letni,

- od 1 listopada do 31 marca - okres zimowy.

W uzasadnionych przypadkach dopuszczalne jest skrócenie lub wydłużenie tych okresów. Powyższe działania należy przeprowadzić co najmniej raz na trzy lata, chyba że w wyniku procesu inwestycyjnego lub z innych względów zmieni się układ zasilania w danej strefie dystrybucyjnej - w takim przypadku należy niezwłocznie ponownie określić strefy nawaniania i/lub obszary nawaniania wraz z lokalizacją punktów nadzoru, w tym analizatora, i dokonać ich weryfikacji. Metodologia wyznaczania minimalnego poziomu stężenia THT w miejscu montażu analizatora zawarta w instrukcji [1] jest następująca:

- należy określić stopień tłumienia stężenia THT w sieci dla okresu letniego i zimowego, przyjmując odpowiednią wartość dla okresu, w którym jest prowadzona kontrola,

- na podstawie wyznaczonego stopnia tłumienia stężenia THT w sieci, z uwzględnieniem minimalnego stężenia THT na jej końcówkach, określonego w PSG na poziomie $15 \mathrm{mg} / \mathrm{m}^{3}$, należy wyznaczyć wartość minimalną stężenia THT w punkcie montażu analizatora.

Do określenia stopnia tłumienia stężenia THT w sieci niezbędne jest przeprowadzenie pomiarów kontrolnych w wyznaczonych dotychczas punktach nadzoru oraz w miejscu montażu analizatora. Powyższe pomiary należy wykonywać w czasie nie dłuższym niż 2 godziny przez kolejne 4 dni dla nastaw nawanialni w okresie maj-sierpień (w przypadku okresu letniego) i grudzień-luty (w przypadku okresu zimowego), wymuszając pomiar na analizatorze przed przystąpieniem do pomiarów oraz po ich zakończeniu. Dla każdej pobranej próbki należy wykonać trzy analizy, a z otrzymanych wyników wyznaczyć wartość średnią. W przypadku gdy jeden $z$ trzech wyników analiz różni się o ponad 10\%, należy wykonać dwie dodatkowe analizy tej próbki, a z uzyskanych pięciu wyników, po odrzuceniu dwóch skrajnych wartości, wyliczyć średnią. Na podstawie otrzymanych rezultatów należy wyznaczyć maksymalny stopień tłumienia stężenia THT w sieci, zgodnie ze wzorem (1). Wszystkie powyższe analizy powinny być wykonane za pomocą chromatografii gazowej.

$$
S_{\max }=\left[\begin{array}{c}
S_{1}=P_{A 1}-P_{\min 1} \\
S_{2}=P_{A 2}-P_{\min 2} \\
S_{3}=P_{A 3}-P_{\min 3} \\
S_{4}=P_{A 4}-P_{\min 4} \\
S_{A}=0
\end{array}\right]
$$

gdzie:

$S_{\max }$ - maksymalny stopień tłumienia THT wyznaczony jako maksymalna wartość z liczb $S_{1}, S_{2}, S_{3}, S_{4}, S_{A}$,

$S_{1}-S_{4}$ - stopień tłumienia wyliczony dla pomiarów wykonanych w poszczególnych dniach,

$P_{A 1}, P_{A 2}, P_{A 3}, P_{A 4}$ - średnia arytmetyczna wyników pomiarów w miejscu montażu analizatora w poszczególnych dniach, wyliczana ze wzoru (2),

$S_{A}$ - stopień tłumienia dla analizatora w każdym dniu w miejscu montażu równy 0 ,

$P_{\min 1}-P_{\min 4}-$ minimalna wartość stężenia THT wybrana ze wszystkich pomiarów wykonanych w punktach nadzoru w danym dniu.

$$
P_{A}=\frac{P_{A R}+P_{A Z}}{2}
$$

gdzie:

$P_{A R}$ - wartość pomiaru stężenia THT wykonanego przed rozpoczęciem poboru próbek w punktach nadzoru w danym dniu,

$P_{A Z}$ - wartość pomiaru stężenia THT wykonanego po zakończeniu poboru próbek w punktach nadzoru w danym dniu.

Na podstawie wyników otrzymanych ze wzorów (1) i (2) wyznacza się minimalny poziom stężenia THT w miejscu montażu analizatora ze wzoru (3).

$$
S_{T H T}=S_{\max }+A
$$


gdzie:

$S_{T H T}$ - minimalny poziom stężenia w miejscu montażu analizatora,
$S_{\max }$ - maksymalny stopień tłumienia wyznaczony ze wzoru (1), $A$ - wartość stała, przyjęta jako minimalna dawka THT na końcówkach sieci.

\section{Przykładowe obliczenia do wyznaczenia minimalnego stężenia THT w miejscu montażu analizatora $\left(S_{T H T}\right)$}

W przykładzie obliczeniowym zaprezentowanym poniżej wykorzystano rzeczywiste dane z wybranej strefy nawaniania. Ze względu na to, że w tej strefie istnieje jedna nawanialnia na stacji gazowej zasilającej tę sieć dystrybucyjną, strefa ta jest jednocześnie obszarem nawaniania.
1. W wyznaczonych punktach nadzoru we wskazanym powyżej obszarze pobrano przez 4 kolejne dni próbki do badań stężenia nawonienia - zgodnie z zapisami instrukcji [1]. Dane z analizy pobranych próbek przedstawiono w tablicy 4 .

Tablica 4. Tabela pomocnicza do wyliczania średniej*

\begin{tabular}{|c|c|c|c|c|c|c|c|c|c|}
\hline \multirow{2}{*}{ Lp. } & \multirow{2}{*}{ Punkt nadzoru } & \multicolumn{2}{|c|}{23.06 .2014} & \multicolumn{2}{|c|}{24.06 .2014} & \multicolumn{2}{|c|}{25.06 .2014} & \multicolumn{2}{|c|}{26.06 .2014} \\
\hline & & GC & średnia & $\mathrm{GC}$ & średnia & GC & średnia & $\mathrm{GC}$ & średnia \\
\hline \multirow{5}{*}{1.} & \multirow{5}{*}{ Ulica A } & 32,1 & \multirow{5}{*}{32,50} & 33,7 & \multirow{5}{*}{34,20} & 32,3 & \multirow{5}{*}{32,43} & 22,8 & \multirow{5}{*}{22,13} \\
\hline & & 32,3 & & 34,0 & & 32,3 & & 21,5 & \\
\hline & & 32,8 & & 34,4 & & 32,7 & & 22,0 & \\
\hline & & 32,5 & & 34,4 & & 32,6 & & 23,1 & \\
\hline & & 32,7 & & 34,2 & & 32,4 & & 21,6 & \\
\hline \multirow{5}{*}{2.} & \multirow{5}{*}{ Ulica B } & 32,7 & \multirow{5}{*}{32,87} & 32,0 & \multirow{5}{*}{32,70} & 33,2 & \multirow{5}{*}{33,47} & 28,8 & \multirow{5}{*}{28,80} \\
\hline & & 32,9 & & 33,0 & & 33,3 & & 28,9 & \\
\hline & & 32,9 & & 32,8 & & 33,6 & & 28,7 & \\
\hline & & 32,8 & & 32,8 & & 33,5 & & 28,6 & \\
\hline & & 32,9 & & 32,5 & & 33,7 & & 28,9 & \\
\hline \multirow{5}{*}{3.} & \multirow{5}{*}{ Ulica C: st. red. II } & 28,7 & \multirow{5}{*}{28,53} & 23,7 & \multirow{5}{*}{24,30} & 32,3 & \multirow{5}{*}{32,17} & 30,9 & \multirow{5}{*}{30,97} \\
\hline & & 28,5 & & 24,4 & & 32,1 & & 30,9 & \\
\hline & & 28,2 & & 24,4 & & 32,2 & & 31,0 & \\
\hline & & 28,5 & & 24,1 & & 32,2 & & 31,3 & \\
\hline & & 28,6 & & 24,5 & & 32,1 & & 31,0 & \\
\hline \multirow{5}{*}{4.} & \multirow{5}{*}{ Ulica D } & 32,4 & \multirow{5}{*}{32,73} & 33,4 & \multirow{5}{*}{33,50} & 25,8 & \multirow{5}{*}{26,23} & 25,2 & \multirow{5}{*}{24,97} \\
\hline & & 32,7 & & 33,7 & & 26,3 & & 25,2 & \\
\hline & & 32,9 & & 33,6 & & 26,6 & & 25,0 & \\
\hline & & 32,7 & & 33,4 & & 26,1 & & 24,3 & \\
\hline & & 32,8 & & 33,5 & & 26,3 & & 24,7 & \\
\hline \multirow[b]{2}{*}{5.} & \multirow[b]{2}{*}{ ANAT (stacja ś/c ulica E) } & 51,0 & & 77,0 & & 52,0 & & 55,0 & \\
\hline & & 31,0 & 41,00 & 29,0 & 53,00 & 34,0 & 43,00 & 32,0 & 43,50 \\
\hline & Wyliczenie $S_{x}$ & $S_{1}$ & 2,47 & $S_{2}$ & 8,70 & $S_{3}$ & 6,77 & $S_{4}$ & 1,37 \\
\hline
\end{tabular}

* Tabela przedstawia przypadek, w którym jeden z trzech powyższych wyników analiz różni się o ponad 10\%, wtedy należy wykonać dwie dodatkowe analizy tej próbki, a z uzyskanych pięciu wyników, po odrzuceniu dwóch skrajnych wartości, wyznaczyć wartość średnią. W przypadku gdy wyniki trzech kolejnych pomiarów nie różnią się o ponad 10\%, należy wyliczyć tylko z tych próbek średnią. - wyniki odrzucone

$S_{A}=0,0 \quad A=15 \quad S_{\max }=28,7$

$S_{T H T}=43,7$, po zaokrągleniu $\boldsymbol{S}_{T H T}=\mathbf{4 4 , 0}$, na podstawie poniższych wyliczeń. 
2. Obliczenia do wyznaczenia minimalnego stężenia THT w miejscu montażu analizatora:

a) Wyznaczenie średniej arytmetycznej wyników pomiarów w miejscu montażu analizatora i w punktach nadzoru:

- w miejscu montażu analizatora w poszczególnych dniach, wyliczana według wzoru poniżej (wyliczenia na podstawie danych z wiersza nr 5 tablicy 4):

$$
\begin{aligned}
& P_{A}=\frac{P_{A_{R}}+P_{A_{Z}}}{2} \\
& P_{A_{1}}=\frac{P_{A_{1 R}}+P_{A_{1 Z}}}{2}=\frac{51+31}{2}=41,00 \mathrm{mg} / \mathrm{m}^{3} \\
& P_{A_{2}}=\frac{P_{A_{2 R}}+P_{A_{2 Z}}}{2}=\frac{77+29}{2}=53,00 \mathrm{mg} / \mathrm{m}^{3} \\
& P_{A_{3}}=\frac{P_{A_{3 R}}+P_{A_{3 Z}}}{2}=\frac{52+34}{2}=43,00 \mathrm{mg} / \mathrm{m}^{3} \\
& P_{A_{4}}=\frac{P_{A_{4 R}}+P_{A_{4 Z}}}{2}=\frac{55+32}{2}=43,50 \mathrm{mg} / \mathrm{m}^{3}
\end{aligned}
$$

- $\quad$ w punktach nadzoru, w których była pobrana próbka; wyliczana dla każdego punktu i każdego dnia; zgodnie z zapisami instrukcji pkt. 6.2.8.3 wyliczenia przedstawiają się następująco:

I. dla dnia 23.06.2014 r.

$$
\begin{aligned}
& P_{\text {min }_{1}}=\left\{\begin{array}{l}
\overline{P_{\mathrm{I}}}=\frac{32,3+32,5+32,7}{3}=32,50 \mathrm{mg} / \mathrm{m}^{3} \\
\overline{P_{\mathrm{II}}}=\frac{32,9+32,8+32,9}{3}=32,87 \mathrm{mg} / \mathrm{m}^{3} \\
\overline{P_{\mathrm{III}}}=\frac{28,5+28,5+28,6}{3}=28,53 \mathrm{mg} / \mathrm{m}^{3} \\
\overline{P_{\mathrm{IV}}}=\frac{32,7+32,7+32,8}{3}=32,73 \mathrm{mg} / \mathrm{m}^{3}
\end{array}\right. \\
& P_{\min 1}=28,53 \mathrm{mg} / \mathrm{m}^{3}
\end{aligned}
$$

II. dla dnia 24.06.2014 r.

$$
\begin{gathered}
P_{\text {min }_{2}}=\left\{\begin{array}{l}
\overline{P_{\mathrm{I}}}=\frac{34,0+34,4+34,2}{3}=34,20 \mathrm{mg} / \mathrm{m}^{3} \\
\overline{P_{\mathrm{II}}}=\frac{32,8+32,8+32,5}{3}=32,70 \mathrm{mg} / \mathrm{m}^{3} \\
\overline{P_{\mathrm{III}}}=\frac{24,4+24,4+24,1}{3}=24,30 \mathrm{mg} / \mathrm{m}^{3} \\
\overline{P_{\mathrm{IV}}}=\frac{33,6+33,4+33,5}{3}=33,50 \mathrm{mg} / \mathrm{m}^{3}
\end{array}\right. \\
P_{\min 2}=24,30 \mathrm{mg} / \mathrm{m}^{3}
\end{gathered}
$$

III. dla dnia 25.06.2014 r.

$$
\begin{aligned}
& P_{\text {min } 3}=\left\{\begin{array}{l}
\overline{P_{\mathrm{I}}}=\frac{32,3+32,6+32,4}{3}=34,43 \mathrm{mg} / \mathrm{m}^{3} \\
\overline{P_{\mathrm{II}}}=\frac{33,3+33,6+33,5}{3}=33,47 \mathrm{mg} / \mathrm{m}^{3} \\
\overline{P_{\mathrm{III}}}=\frac{32,2+32,2+32,1}{3}=32,17 \mathrm{mg} / \mathrm{m}^{3} \\
\overline{P_{\mathrm{IV}}}=\frac{33,6+33,4+33,5}{3}=33,50 \mathrm{mg} / \mathrm{m}^{3}
\end{array}\right. \\
& P_{\min 3}=32,17 \mathrm{mg} / \mathrm{m}^{3}
\end{aligned}
$$

IV. dla dnia 26.06.2014 r.

$$
\begin{aligned}
& P_{\text {min }_{4}}=\left\{\begin{array}{l}
\overline{P_{\mathrm{I}}}=\frac{22,8+22,0+21,6}{3}=22,13 \mathrm{mg} / \mathrm{m}^{3} \\
\overline{P_{\mathrm{II}}}=\frac{28,8+28,9+28,7}{3}=28,80 \mathrm{mg} / \mathrm{m}^{3} \\
\overline{P_{\mathrm{III}}}=\frac{30,9+31,0+31,0}{3}=30,97 \mathrm{mg} / \mathrm{m}^{3} \\
\overline{P_{\mathrm{IV}}}=\frac{33,6+33,4+33,5}{3}=33,50 \mathrm{mg} / \mathrm{m}^{3}
\end{array}\right. \\
& P_{\text {min } 4}=22,13 \mathrm{mg} / \mathrm{m}^{3}
\end{aligned}
$$

b) Wyznaczenie maksymalnego stopnia tłumienia dla każdego dnia; wyliczenia przedstawiają się następująco:

$$
\begin{gathered}
S_{\max }=\left\{\begin{array}{l}
S_{1}=P_{A_{1}}-P_{\text {min }_{1}}=41,00-28,53=12,47 \mathrm{mg} / \mathrm{m}^{3} \\
S_{2}=P_{A_{2}}-P_{\text {min }_{2}}=53,00-24,30=28,70 \mathrm{mg} / \mathrm{m}^{3} \\
S_{3}=P_{A_{3}}-P_{\text {min }_{3}}=43,00-32,17=16,77 \mathrm{mg} / \mathrm{m}^{3} \\
S_{4}=P_{A_{4}}-P_{\text {min }_{4}}=43,50-22,13=21,37 \mathrm{mg} / \mathrm{m}^{3}
\end{array}\right. \\
S_{A}=0 \\
S_{\text {max }}=28,70 \mathrm{mg} / \mathrm{m}^{3}
\end{gathered}
$$

c) Wyznaczenie minimalnego stężenia THT w miejscu montażu analizatora:

$$
S_{T H T}=S_{\max }+\mathrm{A}=28,70+15=43,70 \mathrm{mg} / \mathrm{m}^{3}
$$

Po zaokrągleniu do liczb całkowitych $S_{T H T}$ wynosi:

$$
S_{T H T}=44,00 \mathrm{mg} / \mathrm{m}^{3}
$$

3. W przypadku istniejących analizatorów powyższe pomiary i obliczenia wykonuje się dla okresu letniego i zimowego, a następnie przyjmuje się wyliczone $S_{T H T}$ odpowiednio do danego okresu. Przy planowanych montażach analizatorów należy wykonać pomiary przynajmniej dla jednego z okresów, a po montażu uzupełnić pomiary i obliczenia dla brakującego okresu.

\section{Podsumowanie}

Rozliczanie w jednostkach energii wymaga spójnego i przejrzystego systemu pozyskiwania danych o cieple spalania, opartego na współpracy wszystkich podmiotów obec- nych na rynku gazu w Polsce. Niezbędne do funkcjonowania takiego systemu jest uregulowanie odpowiedzialności i uprawnień poszczególnych podmiotów oraz określenie 
metod pozyskiwania danych, które będą stanowić podstawę rozliczeń z odbiorcą końcowym. Takie działania pozwolą na wiarygodniejsze porównywanie opłat oraz zapewnią większą przejrzystość rozliczeń dla odbiorców końcowych.

Ciągłe i systematyczne monitorowanie poziomu stężenia THT za pomocą analizatorów pozwala na niezwłoczną reakcję służb dyspozycji gazu na stany alarmowe, takie jak zaniżony bądź zawyżony poziom nawonienia, i równocześnie zmniejsza znacząco liczbę wyjazdów służb badają- cych poziom THT, co powoduje ograniczenie kosztów z tym związanych.

Korzystanie z wyżej wymienionych urządzeń pozwala dodatkowo na utrzymywanie optymalnego poziomu nawonienia poprzez zapewnianie właściwej dawki THT dozowanej do sieci dystrybucyjnej i ograniczenie kosztów związanych z nieuzasadnionymi interwencjami służb pogotowia gazowego oraz z zakupem środka nawaniającego, przy jednoczesnym zachowaniu wymagań bezpieczeństwa.

Prosimy cytować jako: Nafta-Gaz 2016, nr 8, s. 651-659, DOI: 10.18668/NG.2016.08.10

Artykuł nadesłano do Redakcji 1.02.2016 r. Zatwierdzono do druku 27.04.2016 r.

Artykuł powstał na podstawie referatu zaprezentowanego na Konferencji Naukowo-Technicznej FORGAZ 2016 „Techniki i technologie dla gazownictwa - pomiary, badania, eksploatacja”, zorganizowanej przez INiG - PIB w dniach 13-15 stycznia 2016 r. w Muszynie.

\section{Literatura}

[1] Instrukcja prowadzenia nadzoru nad nawonieniem gazu ziemnego (Zarządzenie Nr 119/2015 Prezesa Zarządu Polskiej Spółki Gazownictwa w Warszawie z dnia 24 listopada 2015 r.).

[2] Rozporządzenie Ministra Gospodarki z dnia 28 czerwca 2013 r. w sprawie szczegółowych zasad kształtowania i kalkulacji taryf oraz rozliczeń w obrocie paliwami gazowymi (Dz. U. poz. 820).

[3] Rozporządzenie Ministra Gospodarki z dnia 2 lipca $2010 \mathrm{r}$. w sprawie szczegółowych warunków funkcjonowania systemu gazowego (Dz. U. Nr 133, poz. 891).

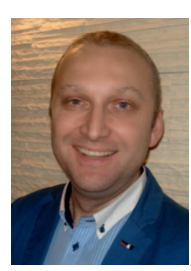

Wojciech LASZUK

Główny Specjalista ds. Jakości Paliwa Gazowego

Departament Transportu Gazu

Polska Spółka Gazownictwa Sp. z o.o.

Centrala Spółki

ul. M. Kasprzaka 25, 01-224 Warszawa

E-mail:wojciech.laszuk@psgaz.pl

\section{OFERTA}

\section{ZAKŁAD INFORMATYKI}

Zakres działania:

- zastosowanie matematyki i technologii informatycznych do:

» konstrukcji dziedzinowych systemów eksperckich,

» budowy i eksploatacji baz danych i baz wiedzy,

» wykorzystania metod analiz ryzyka,

» konstrukcji Systemu Zarządzania Integralnością Gazociągów,

" budowy komputerowych systemów wspomagania decyzji,

" analizy statystycznej wyników eksperymentów badawczych,

» tworzenia unikatowego oprogramowania,

- zarządzanie siecią komputerową i dostępem do internetu w ramach sieci korporacyjnej INiG - PIB.

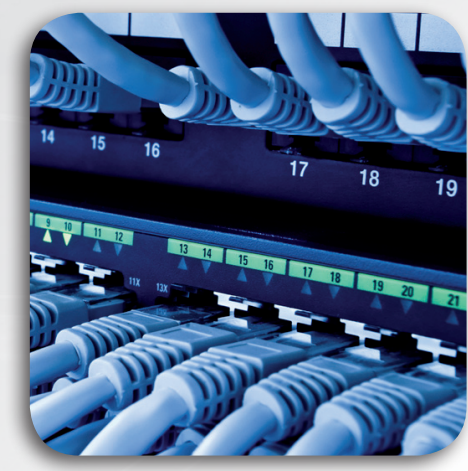

